\title{
A needed balance
}

\author{
Governments need to act now to halt rising inequalities or they will fail to deliver on the promise of a better \\ future for all.
}

T he enduring impacts of the COVID19 pandemic and the more recent Black Lives Matter protests have been shaking societies across the world. What is at the heart of so much social disorder? It's inequality, many argue. We agree. No matter in which country one lives, the threats, the challenges, the missed opportunities, the impacts of policies are different depending on which social group one belongs to. Is it the high- or low-income group? Is it the dominant or the minority ethnic group? The list goes on. Within-country inequality has been growing high on the agenda of development scholars and experts among others for quite some time now, not so much of politicians. Not until now at least.

At the onset of the 2008 financial crisis, countries like the United States, United Kingdom, Germany and others saw the governments bailing out banks while the economies were slowing down. The resulting increase in government deficits led to austerity policies aimed at reducing such deficits mostly through spending cuts. Did such policies affect everyone equally? Most certainly not. In 2017, a report from the secretariat of the United Nations Conference on Trade and Development titled Beyond Austerity: towards a global new deal, argues how the world economy remains unbalanced, despite the Agenda 2030 ambitions as reflected in SDG 10 'Reduce inequalities within and among countries'. Deep inequalities - able to destabilize the political, social and environmental health of the planet - pre-existed austerity measures and got worse because of such measures. Poorer communities were hit the hardest leading to even more polarization while the most vulnerable experienced increasing anxiety about the future. Now the COVID19 pandemic has heightened the situation with poorer, most vulnerable and minority groups suffering much greater health and socio-economic impacts than the rest of the population. As highlighted by Lise Kingo, the CEO and Executive Director of the United Nations Global Compact initiative, the pandemic has simply revealed the fragilities of our global system. In her view, business leaders should become social activists and understand social inequality because it is the right thing to do and because it creates stability across the world. She is not alone in seeing a connection among the impacts of the COVID-19 and climate change crises, and more recently the Black Lives Matter movement. Sustainable development hinges on a more equal and a fairer world. We cannot tackle climate change, biodiversity loss and environmental degradation if we ignore social inequalities. Likewise, we cannot succeed at eliminating social inequalities if we neglect environmental damage.

How can inequality be eradicated? The first step is to admit, rather than closing an eye on, that inequalities are all around us and are too large to be justified on grounds of different abilities and aspirations among individuals. When they are so large, they harm society and the natural world. Scholars and practitioners from various disciplines sent the alarm long ago. There are many accounts in the scholarly domain of the extent to which societies characterized by uneven income distribution score poorly in terms of social order - poor health and low life expectancy, high levels of crime, poor school educational attainment, low social mobility, low social capital, high expressions of racism, substantial gender gaps and so on. Besides, uneven power structures aggravate social dysfunction through various channels. For example, in 2003, Boyce discussed evidence that when those who stand to gain from environmentally damaging activities have more power than those who stand to lose the most from such activities, the result is more iniquities in terms of class, race, ethnicity, gender and age. This is in addition to the fact that social inequalities have direct impact on environmental quality. More recently, a review of published work by Hamann and colleagues draws on diverse disciplines to provide a systemic understanding of the connections between inequality and the biosphere and highlights the complex nature of inequality. Though more interdisciplinary work to shed light on such a conundrum is welcome, including in Nature Sustainability, it's time to focus on finding effective solutions. So we urge decision makers - and in particular politicians - to take stock of available evidence, and admit that the issue is real, it is worsening and it is dangerous.

Then, action should come. Do we need new policy tools? We don't think so. We need willingness to embrace the complexity of human-nature interfaces like the social inequality-biosphere health one, at all levels of governance and policy. We need stronger and competent political intervention to stop practices fuelling inequalities such as environmentally damaging activities, and to enable change in institutional and cultural settings now favouring racism, imbalance of power structures, gender and minority group gaps, among other issues. It's time for politicians to prioritize above all the well-being of all citizens by providing fair access to basic services, equal wealth and by eradicating inequality of opportunities, the worst dimension of inequality according to Stiglitz (The Great Divide, 2015).

Halting the inequality spiral with decisive political action will make societies and economies stronger and more sustainable over the long term. There is need of business courage to change the profit baseline and respond to societal calls for a more equitable and environmentally sustainable economy. Citizens have a duty to hold those in power accountable for their actions. And those in power have to listen to citizens around the world as they won't tolerate neglect, injustice and unfairness any longer. A fairer future can be achieved but it requires willingness to change the status quo, accepting some costs and eliminating unfair privilege. It's a balancing act across thriving socio-economic opportunities for all, access to healthcare and other basic services for all and environmental sustainability globally. We know such balance can be achieved: we have made the system we live in; therefore, we can change it. And we want to get that done soon. For this we need decision makers to stop promising and start acting today.

Published online: 15 July 2020 https://doi.org/10.1038/s41893-020-0584-8 